\title{
Effect of Climate Change on the Yield of Cereal Crops: A Review
}

\author{
Jin Wang ${ }^{(1)}$, Sai Kranthi Vanga *(D), Rachit Saxena, Valérie Orsat and Vijaya Raghavan \\ Department of Bioresource Engineering, Faculty of Agricultural and Environmental Sciences, McGill University, \\ 21111 Lakeshore Rd, Sainte-Anne-de-Bellevue, QC H9X 3V9, Canada; jin.wang6@mail.mcgill.ca (J.W.); \\ rachit.saxena@mail.mcgill.ca (R.S.); valerie.orsat@mcgill.ca (V.O.); vijaya.raghavan@mcgill.ca (V.R.) \\ * Correspondence: sai.vanga@mail.mcgill.ca
}

Received: 29 April 2018; Accepted: 13 May 2018; Published: 15 May 2018

\begin{abstract}
By the end of this century, the average global temperature is predicted to rise due to the increasing release of greenhouse gases (GHGs) into the atmosphere. This change in climate can reduce agricultural yields, resulting in food insecurity. However, agricultural activities are one of the major contributors of GHGs and lower yields can trigger increased activity to meet the demand for food, resulting in higher quantities of GHGs released into the atmosphere. In this paper, we discuss the growth requirements and greenhouse gas release potential of staple cereal crops and assess the impact of climate change on their yields. Potential solutions for minimizing the influence of climate change on crop productivity are discussed. These include breeding to obtain cereals that are more tolerant to conditions caused by climate change, increased production of these new cultivars, improved irrigation, and more effective use of fertilizers. Furthermore, different predictive models inferred that climate change would reduce production of major cereal crops, except for millets due to their ability to grow in variable climatic conditions, and in dry areas due to a strong root system. Moreover, millets are not resource-intensive crops and release fewer greenhouse gases compared to other cereals. Therefore, in addition to addressing food security, millets have an enormous potential use for reducing the impact of agriculture on global warming and should be grown on a global scale as an alternative to major cereals and grains.
\end{abstract}

Keywords: climate change; cereal crop yield; irrigation and fertilizer efficiency; food security; millets

\section{Introduction}

Cereal grains including wheat, maize, and paddy are considered primary crops as they are staple foods to most of the population across the globe. By 2050, a 70-100\% increase in cereal food supply is required to feed the predicted world population of 9.8 billion people [1]. Boosting the production rates is generally accepted as the solution to meet the increasing demand, but historic figures show that the current production rates are nowhere near what is required to meet the targets [2]. Furthermore, this problem is further compounded with a drastic reduction in the amount of fertile and arable land available to grow these crops, which is expected to continue to decrease into the future due to current agricultural practices [3]. Researchers agree that global climate change can have an impact on the production yields of crops and is an issue that must be addressed for attaining food security $[4,5]$. Studies have shown that the earth will be warmer in the future, with the average surface temperature increasing at a pace of roughly $0.2{ }^{\circ} \mathrm{C}$ per decade over the next 30 years. Furthermore, estimates show that global temperatures will increase by 2.5 to $4.5^{\circ} \mathrm{C}$ by the end of the 21st century as a result of the rising concentrations of greenhouse gases (GHGS; e.g., $\mathrm{CO}_{2}$ and $\mathrm{CH}_{4}$ ) in the atmosphere [6,7]. Global warming can reduce the net carbon gain by increasing plant respiration rates, which in turn would decrease the production yield of crops and could even result in the invasion of weed, pathogens, 
and pests [8,9]. For example, during the cultivation of wheat, an increase in temperature by $1^{\circ} \mathrm{C}$ could reduce production yields by 3 to $10 \%$ [10]. In a world where population size is soaring and reaching unsustainable levels, a drastic reduction in agricultural yields of major cereal crops can significantly hinder ensuring food security.

To resolve this problem, the scientific community must find alternative crops that can be adapted and cultivated despite the global warming phenomenon. Concurrently, these crops should also be able to release less greenhouse gases, must be less resource-intensive, and be rich in major and minor nutrients required for our well-being. Millets are cereal crops that have many of the desirable attributes mentioned above when compared to other major crops (e.g., wheat, paddy and maize) [11]. Millets are hardy cereal crops with short growth periods that are roughly between 60-100 days depending on the variety. Millets are drought-tolerant crops that can be grown under a wide range of weather conditions [12]. Moreover, researchers have shown that millets release less greenhouse gases, which could be beneficial in reducing the contributions of the agri-food sector to global warming [11]. In a scenario, where water and food crises are staring at us in the face, millets can become a major food for achieving the targets of food and nutritional security. Millets as a replacement are further favored by the fact that, when compared with crops such as maize and paddy, they are less resource-intensive; i.e., they require significantly lower soil quality, and lower inputs of water and fertilizers. For example, paddy requires large quantities of water during their growth and drought conditions can have direct implications on a significant drop in yield [13]. Also, there are several other possible strategies including breeding, technical progress, and improving fertilizer efficiency to increase cereal crops production.

While climate change has the potential to influence the cereal yield directly by heat and water stresses, it can also have an indirect impact by affecting the fertilizer supply, pathogens, and pests [14]. The majority of researchers agree that global warming is irreversible over a short period and requires global policy change and sustainable agricultural practices for a long period to mitigate and reverse the environmental damage. The primary objective of this review is to assess the influence of climate change on the projected yields of major cereal crops. Various solutions have also been presented along with the promotion of millets for crop diversification, especially in the regions where food insecurity will be prevalent. However, it is important to note that there are numerous factors that lead to uncertainity in yield predictions, especially in the regions with poor soil and water conditions.

\section{Production Data-Cereal Crops}

Table 1 lists the production quantities of various cereal crops around the world and the total area in which they are planted in 2016. The tabulated data shows that, of the cereals listed in the table, the largest area of agricultural land dedicated to the production of maize is in the Americas (Table 1) [15]. Specifically, 70.1 Mha is used to cultivate maize in the Americas, followed by $63.5 \mathrm{Mha}$ in Asia. Hence, the highest maize production in terms of quantity was in the Americas, accounting for $52 \%$ of the total world production followed by Asia (31\%), Europe (11\%) and Africa (6\%). Asia, where a majority of the global population resides, accounted for $90.1 \%$ of the world's production of paddy. Furthermore, Asia produces $47.2 \%$ and $43.6 \%$ of the world production of millet and wheat, respectively. In Asia, paddy, millet, and wheat were cultivated on 140.5 Mha, 10.9 Mha, and 100.5 Mha of agricultural land, respectively. As shown in Table 2, the top five producers of paddy in 2016 were: China (209.5 MT), India (158.7 MT), Indonesia (77.3 MT), Bangladesh (52.6 MT), and Vietnam (43.4 MT). However, the yields of paddy production vary widely: the highest was $6.9 \mathrm{tha}^{-1}$ in China and the lowest was $3.7 \mathrm{t} \mathrm{ha}^{-1}$ in India [15].

China was also the largest producer of wheat in 2016, with a total production of 131.7 MT, followed by India with 93.5 MT. Russia and US also produced significant quantities of wheat with total productions of 73.3 MT and 62.9 MT, respectively. Canada produced 30.5 Mt with a yield of $3.3 \mathrm{tha}{ }^{-1}$. The wheat yields were also significantly higher in China $\left(5.4 \mathrm{t} \mathrm{ha}^{-1}\right)$ compared to the US, Canada, and India, whose yields varied between 3 and $3.5 \mathrm{t} \mathrm{ha}^{-1}$. The top producer of maize in 2016 was the US 
(384.8 MT), accounting for 36.3\% of the world's total production, followed by China (231.7 MT), Brazil (64.1 MT), Argentina (39.8 MT), and Mexico (28.3 MT). The yield of maize was found to be significantly higher in the US with $11.0 \mathrm{t} \mathrm{ha}^{-1}$ followed by Argentina with $7.4 \mathrm{t} \mathrm{ha}^{-1}$. India is the largest producer of millet (10.3 MT) followed by Niger (3.9 MT) and China (2.0 MT). Mali and Nigeria produced 1.8 MT and 1.5 MT, respectively. However, the yields were significantly higher in China at $2.7 \mathrm{tha}^{-1}$ followed by India $\left(1.2 \mathrm{tha}^{-1}\right)$.

Table 1. The production and planting area of different crops all over the world in the year of 2016.

\begin{tabular}{ccccccccc}
\hline Region & $\begin{array}{c}\text { Maize Area } \\
\text { (Mha) }\end{array}$ & $\begin{array}{c}\text { Maize Yield } \\
\text { (MT) }\end{array}$ & $\begin{array}{c}\text { Paddy Area } \\
\text { (Mha) }\end{array}$ & $\begin{array}{c}\text { Paddy Yield } \\
\text { (MT) }\end{array}$ & $\begin{array}{c}\text { Millet Area } \\
\text { (Mha) }\end{array}$ & $\begin{array}{c}\text { Millet Yield } \\
\text { (MT) }\end{array}$ & $\begin{array}{c}\text { Wheat Area } \\
\text { (Mha) }\end{array}$ & $\begin{array}{c}\text { Wheat Yield } \\
\text { (MT) }\end{array}$ \\
\hline Africa & 36.6 & 77.8 & 12.5 & 32.5 & 20.0 & 13.6 & 8.9 & 23.1 \\
Americas & 70.1 & 547.4 & 6.1 & 36.0 & 0.2 & 0.3 & 36.9 & 126.7 \\
Asia & 63.5 & 324.1 & 140.5 & 667.9 & 10.9 & 13.8 & 100.4 & 326.7 \\
Europe & 17.7 & 117.4 & 0.6 & 4.2 & 0.6 & 0.9 & 62.5 & 250.1 \\
Oceania & 0.07 & 0.6 & 0.03 & 0.3 & 0.04 & 0.03 & 11.3 \\
World & 187.9 & 1060.1 & 159.8 & 740.9 & 31.7 & 28.3 & 220.1 \\
\hline
\end{tabular}

(Source: FAOSTAT, 2017).

Table 2. List of largest producing countries of agricultural crops in 2016.

\begin{tabular}{ccccccccccc}
\hline Crop & First & $\begin{array}{l}\text { Yield } \\
(\mathbf{M T})\end{array}$ & Second & $\begin{array}{c}\text { Yield } \\
\mathbf{( M T )}\end{array}$ & Third & $\begin{array}{c}\text { Yield } \\
(\mathbf{M T})\end{array}$ & Fourth & $\begin{array}{c}\text { Yield } \\
\text { (MT) }\end{array}$ & $\begin{array}{c}\text { Fifth } \\
\text { Yield } \\
\text { (MT) }\end{array}$ \\
\hline Paddy & China & 211.1 & India & 158.8 & Indonesia & 77.3 & Bangladesh & 52.6 & Vietnam & 43.4 \\
Millet & India & 10.2 & Niger & 3.9 & China & 2.0 & Mali & 1.8 & Burkina Faso & 1.1 \\
Wheat & China & 131.7 & India & 93.5 & Russia & 73.3 & USA & 62.8 & France & 29.5 \\
Maize & USA & 384.7 & China & 231.8 & Brazil & 64.1 & Argentina & 39.8 & Ukraine & 28.1 \\
\hline
\end{tabular}

(Source: FAOSTAT, 2017).

The production data shows that China is the largest producer of cereal crops in the world producing $28.5 \%, 17.6 \%$ and $21.8 \%$ of paddy, wheat, and maize respectively. India also produces significant quantities of cereal crops. It produces $21.4 \%, 12.6 \%$, and $36.3 \%$ of the world's production of paddy, wheat, and millets, respectively. These two countries house $36.7 \%$ of the world population and hence must produce a huge quantity of cereals to provide food security to their population. However, major differences exist between these countries in terms of their yields; China produces cereal grains at significantly higher rates compared to India. Due to the growing populations in these countries, the stress on resources like soil and water are increased, leading to the accelerated deterioration of the environment $[16,17]$.

\section{Required Growing Condition of Different Crops}

\subsection{Paddy}

Paddy (Oryza sativa) or rice paddy, is normally grown in water-flooded fields in more than 95 countries and plays a vital role in feeding large sections of the world's population, especially in India and China [18]. As shown in Table 3, paddy cultivation needs a significant amount of water, estimated to be around 500 to $600 \mathrm{~mm}$. The optimal temperature for growth was reported to be between 22 and $31{ }^{\circ} \mathrm{C}$, and requires 5 to $6 \mathrm{~h}$ of sunshine per day [13]. Many studies have shown that climatic conditions (rainfall, irrigation, temperature) can have a significant effect on the yield of crops. A report showed that the yield of paddy (YLY6) was $8.23 \mathrm{t} \mathrm{ha}^{-1}$ when the 'continuous flooding method' was employed [13]. This is higher than when paddy was grown using the alternate 'wetting and drying irrigation system' ( $\left.7.98 \mathrm{tha}^{-1}\right)$, which was adopted in regions having a limited supply of water. In the continuous flooding system, the amount of irrigation water supplied was $296 \mathrm{~mm}$ while rainfall water on the field was estimated to be $533 \mathrm{~mm}$ throughout the growing period. In the 'wetting and drying system', the amount of water supplied by rainfall remained constant, while irrigation water was reduced to $224 \mathrm{~mm}$. 
As shown in Table 4, the optimal soil $\mathrm{pH}$ for paddy growth ranged from 5.0 to 6.5 [19]. Paddy requires $90-120 \mathrm{~kg} \mathrm{ha}^{-1}$ of nitrogen $(\mathrm{N}), 30-40 \mathrm{~kg} \mathrm{ha}^{-1}$ of phosphorous (P), and 40-60 $\mathrm{kg} \mathrm{ha}^{-1}$ of potassium $(\mathrm{K})$ throughout its cultivation period [20]. In addition to high water and nutrient requirements, pesticides must be used to reduce crop spoilage, which results in contamination of surface water by heavy metals, which are discharged into rivers and lakes [21].

\subsection{Millet}

Millets are one of the major crops traditionally grown for thousands of years for human consumption in India, China, and Africa, due to its higher nutritive values (high protein content, $11 \mathrm{~g}$ protein $/ 100 \mathrm{~g}$ ) [22]. Millet species that are commonly cultivated around the world are proso, pearl, finger, kodo, and foxtail [23]. Millet is a drought-resistant cereal crop with a short growth duration that varies between 60 to 100 days [24]. Millet crops range from 30 to $100 \mathrm{~cm}$ in height and have a strong rooting system and generally require no fertilizer. Millet is a C4 crop; i.e., it has the capacity to fix carbon even under high temperatures and low nitrogen conditions due to its low transpiration rate $[24,25]$. As shown in Table 3, the optimal growing temperature for millets is 20 to $35^{\circ} \mathrm{C}$ with 4 to $6 \mathrm{~h}$ of sunshine per day. Millet can be grown in sandy, salty, alkaline, and acidic soils; thus, the optimal pH ranges widely between 4.5 to 8.0 (Table 4). Moreover, the nutrient requirement for millets is minimal, and a few millet varieties can be grown in soils (sandy loam, slightly acidic soils) with low fertility [26]. Furthermore, most millets are pest free due to their strong disease resistance traits, which could be a key to reducing the use of pesticides and the consequent pollution caused by pesticide use.

\subsection{Maize}

Maize (Zea mays L.) is a wild grass also known as corn or Indian corn and belongs to the Poaceae (Gramineae) family. It was domesticated more than 7,000 years ago in Mexico and has spread rapidly throughout North and South America as a primary crop [27]. In terms of production, maize ranks third after wheat and paddy [28]. In both developed and developing countries, it is a major crop for human and animal consumption because it is rich in carbohydrates (76-88\%), protein (6-16\%), fat $(4-5.7 \%)$, and minerals (1.3\%) [29]. As shown in Table 3, maize is a warm-season crop and the optimal temperature requirement is 11 to $30{ }^{\circ} \mathrm{C}$ with 5 to $6 \mathrm{~h}$ of sunshine per day. It requires nutrient-rich and moist soil with a $\mathrm{pH}$ ranging between 5.8 to 7.0 for its cultivation. The rainfall requirement is 200 to $450 \mathrm{~mm}$ during the growing season [30] and the whole growing duration is 90 to 110 days. Application of fertilizer is commonly recommended with 125 to $160 \mathrm{~kg} \mathrm{~N}, 55$ to $80 \mathrm{~kg}$ phosphorous pentoxide $\left(\mathrm{P}_{2} \mathrm{O}_{5}\right)$, and 85 to $110 \mathrm{~kg}$ potassium oxide $\left(\mathrm{K}_{2} \mathrm{O}\right)$ per hectare (Table 4). Maize gives good yield in silt loamy soil and is a $\mathrm{C} 4$ plant, like millets, which makes it a considerably water-efficient crop compared to C3 plants (soybean, wheat). This feature enables maize to be more temperature resistant and provides the capacity to fix more carbon [29-31].

\subsection{Wheat}

Wheat (Triticum spp.) is the most widely cultivated cereal crop and is commonly consumed in many parts of the world. Wheat is classified as either winter wheat or spring wheat, according to the season during which the crop is grown [32]. The winter wheat sprouts before freezing occurs, then becomes dormant until the soil warms in the spring. It also requires a few weeks of cold before being able to flower. Normally, it is sowed in October and November and is ready to be harvested by June and July. For the spring crop, wheat is usually planted between March and May and should be harvested between July and September. Spring wheat has a growing cycle of four months, which is considerably shorter than that for winter wheat. As shown in Table 3, the growing temperature for wheat is -3 to $23^{\circ} \mathrm{C}$ with a 120 to 180 day growing period, and it requires 4 to $6 \mathrm{~h}$ sunshine per day. It can be grown in sandy loam soils and the optimum soil pH range is from 5.5 to 6.5 (Table 4). The nutrient requirements 
for optimal yields are 70-200 $\mathrm{kg} \mathrm{ha}^{-1} \mathrm{~N}, 20-40 \mathrm{~kg} \mathrm{ha}^{-1} \mathrm{P}$, and 80-100 $\mathrm{kg} \mathrm{ha}^{-1} \mathrm{~K}$, which are higher than that required by maize $[15,33,34]$.

Table 3. The requirements of rainfall, irrigation, temperature, sunshine, and duration of growth for various cereal crops.

\begin{tabular}{ccccccc}
\hline Species & $\begin{array}{c}\text { Irrigation } \\
(\mathbf{m m})\end{array}$ & $\begin{array}{c}\text { Temperature } \\
\left.\mathbf{(}{ }^{\circ} \mathbf{C}\right)\end{array}$ & $\begin{array}{c}\text { Sunshine } \\
\mathbf{( h / d )}\end{array}$ & $\begin{array}{c}\text { Duration of } \\
\text { Growth }(\mathbf{d})\end{array}$ & $\begin{array}{c}\text { Photosynthesis } \\
\text { Pathway }\end{array}$ & References \\
\hline Paddy & $500-600$ & $22-31$ & $4-6$ & $90-120$ & C3 & {$[13,15]$} \\
Millet & 0 & $20-35$ & $4-5$ & $60-100$ & C4 & {$[24,25]$} \\
Wheat & $60-90$ & $-3-23$ & $4-6$ & $120-180$ & C3 & {$[15,31,32]$} \\
Maize & $40-50$ & $11-30$ & $6-7$ & $90-110$ & C4 & {$[15,29]$} \\
\hline
\end{tabular}

Table 4. The requirement of soil condition, fertilizer, and pesticide of various crops. mi.

\begin{tabular}{cccccccc}
\hline Species & Soil $\mathbf{~ H ~}$ & Soil Type & $\mathbf{N ~ ( k g / h a )}$ & $\mathbf{P}(\mathbf{k g} / \mathbf{h a})$ & $\mathbf{K} \mathbf{~ ( k g / h a )}$ & Pesticide & References \\
\hline Paddy & $5.0-6.5$ & flooded field & $90-120$ & $30-40$ & $40-60$ & Yes & {$[19,20]$} \\
Millet & $4.5-8.0$ & saline, sandy, clay loams & $\mathrm{No}^{*}$ & $\mathrm{No}^{*}$ & No * & No * & {$[24-26]$} \\
Wheat & $5.5-6.5$ & sandy loam & $70-200$ & $20-40$ & $80-100$ & Yes & {$[15,32-34]$} \\
Maize & $5.8-7.0$ & warm and silt loams & $125-160$ & $55-80$ & $85-110$ & Yes & {$[29-31]$} \\
\hline
\end{tabular}

${ }^{*}$ Minimal use of fertilizers and pesticides compared to other cereals.

\section{Greenhouse Gases from Different Crops}

The release of GHG including carbon dioxide $\left(\mathrm{CO}_{2}\right)$, methane $\left(\mathrm{CH}_{4}\right)$, and nitrous oxide $\left(\mathrm{N}_{2} \mathrm{O}\right)$ from various crops are not well studied compared to the emission of GHGs from other industrial sectors (e.g., coal and oil), especially in the developing world [35]. Even the data presented in the few studies conducted are highly variable due to the variability associated with the agricultural conditions in any particular region. Recent research has shown that global concentrations of $\mathrm{CO}_{2}$, $\mathrm{N}_{2} \mathrm{O}$, and $\mathrm{CH}_{4}$ are increasing rapidly and currently are $40 \%, 20 \%$, and $150 \%$ of pre-industrial age levels, with agricultural operations being one of the major contributors to this phenomenon. Due to the greenhouse gas effect, the increase in GHG levels can have a substantial impact on temperatures and consequently on climatic conditions [11,36-38].

Global warming potential (GWP) is an estimate to assess the total amount of heat that can be trapped in the atmosphere due to GHGs. It is defined by the Intergovernmental Panel on Climate Change (IPCC) as "the radiative forcing following a pulse emission of a unit mass of a given greenhouse gas in the present day atmosphere integrated over a chosen time horizon, relative to that of carbon dioxide" [39]. The assessment of the potential is made either based on a 20- or 100-year duration and generally it is assumed that the longer the gas is present in the atmosphere, the lower is its potency (can have exceptions Ex: Sulfur hexafluoride) [40]. Simply, if a GHG has a higher thermal absorption rate and takes longer to degrade, it has a higher GWP.

The GWP of various cereal crops like rice, wheat, maize and millets have been calculated which are reported in Table 5. Multiple studies including life cycle analyses have been conducted in different parts of the world to assess the GWPs based on the regional data. The GWPs can vary widely based on agricultural practices, availability of irrigation systems, fertilizer applications, availability and mode of transportation as all these factors play a role in GHGs released into the atmosphere (Table 5) [11,41-49]. Carbon equivalent emission (CEE) is just a measure of total carbon equivalents calculated based on the GWP (which is the $\mathrm{CO}_{2}$ equivalents). $\mathrm{CEE}$ is obtained by using the following equation.

$$
E E=G W P \times \frac{\text { atomic weight of carbon }}{\text { Molecular weight of } \mathrm{CO}_{2}}=G W P \times \frac{12}{44}
$$

Various researchers have evaluated the GWP of three major cereals rice, wheat, and maize in multiple parts of the world and reported that it can vary widely based on the aforementioned factors. 
The GWP for these cereals was found to reach 17,000-19,000 $\mathrm{kg} \mathrm{CO}_{2}$ eq. ha ${ }^{-1}$. However, comprehensive data on the GWP of other, cereals like millets and sorghum, are missing. Jain et al., was the first to evaluate the GWP of millet along with other major cereals [11]. It must be noted that the cerelas crops in this study were fertilized. The mean available $\mathrm{N}, \mathrm{P}$, and $\mathrm{K}$ in the plot used for rice cultivation is reported to be $9.62 \mathrm{~kg} \mathrm{ha}^{-1}, 17 \mathrm{~kg} \mathrm{ha}^{-1}$, and $335 \mathrm{~kg} \mathrm{ha}^{-1}$, whereas in the plots used for other cereal crops they were $17.7 \mathrm{~kg} \mathrm{ha}^{-1}, 15.6 \mathrm{~kg} \mathrm{ha}^{-1}$, and $312 \mathrm{~kg} \mathrm{ha}^{-1}$, respectively. In this study, the mean GWP and CEE for the five cereal crops was estimated to be $3598 \mathrm{~kg} \mathrm{CO}_{2}$ eq. ha ${ }^{-1}$ and $977 \mathrm{~kg} \mathrm{C} \mathrm{ha}^{-1}$ [11]. Wheat showed the highest GWP with $3968 \mathrm{~kg} \mathrm{CO}_{2}$ eq. ha ${ }^{-1}$, followed by maize $\left(3427 \mathrm{~kg} \mathrm{CO}_{2}\right.$ eq. ha $\left.{ }^{-1}\right)$ and rice ( $3401 \mathrm{~kg} \mathrm{CO}_{2}$ eq. ha ${ }^{-1}$ ). Millets have the lowest GWP with $3218 \mathrm{~kg} \mathrm{CO}_{2}$ eq. ha ${ }^{-1}$ for pearl millet (a minor millet) and $3358 \mathrm{~kg} \mathrm{CO}_{2}$ eq. ha ${ }^{-1}$ for sorghum (a major millet). The CEE of different crops have showed that millets have the lowest carbon emissions $\left(878 \mathrm{~kg} \mathrm{C} \mathrm{ha}^{-1}\right)$, followed by sorghum with $916 \mathrm{~kg} \mathrm{C} \mathrm{ha}^{-1}$. The highest carbon emission was released by wheat $\left(1042 \mathrm{~kg} \mathrm{C} \mathrm{ha}^{-1}\right)$. Hence, to reduce greenhouse emissions from agricultural activity, cultivating millets will be a better option, which in turn could be beneficial in reducing global warming. Furthermore, a comprehensive life cycle analysis must be performed on millets to confirm the lower GWPs when transportation and other factors are also included.

Table 5. Seasonal flux of global warming potential and carbon equivalent emission from soil under different crops ([11,41-49]).

\begin{tabular}{|c|c|c|}
\hline Crop & $\begin{array}{l}\text { Global Warming Potential } \\
\left(\mathrm{Kg} \mathrm{CO}_{2} \text { eq. } \mathrm{ha}^{-1}\right)\end{array}$ & $\begin{array}{l}\text { Carbon Equivalent Emission } \\
\left(\mathrm{kg} \mathrm{C} \mathrm{ha}^{-1}\right)\end{array}$ \\
\hline Rice & $2890-17,000$ & $956-4600$ \\
\hline Millet & 3218 & 878 \\
\hline Wheat & $2000-18,000$ & $545-4900$ \\
\hline Maize & $3427-17,600$ & $935-4800$ \\
\hline Sorghum & 3358 & 916 \\
\hline Rice-Wheat * & $7137-18,000$ & $2000-4900$ \\
\hline Wheat-Maize * & $12,880-18,850$ & $3512-5100$ \\
\hline
\end{tabular}

\section{Climate Change Impact on Crops Yield and Food Security}

\subsection{Paddy}

Many studies showed that growing conditions (e.g., irrigation, temperature, fertilizer supply) play a vital role in the final yield of paddy. The study reported that the yields of paddy (Xiushui 134) under an alternate wetting and drying irrigation system were reduced significantly when compared to yields using continuous flooding irrigation [50]. The same study also evaluated the controlled release of nitrogen fertilizer under the alternate wetting and drying (AWD) irrigation system. In the wetting and drying method, the supply of irrigation water was decreased by $28 \%$ and $42 \%$ in the two years of experimentations compared to the flooding method. Despite the lower consumption, this method performed better with higher paddy yield and plant biomass such as root, shoot, and panicle. Specifically, AWD irrigation increased the grain yield by $5.7-6.6 \%$ in the two years of experimentation. Paddy yields in fields fertilized with conventional urea at $240 \mathrm{~kg} \mathrm{~N}^{-1}$, controlled-release bulk blending fertilizer at $240 \mathrm{~kg} \mathrm{~N} \mathrm{ha}^{-1}$ and polymer-coated urea at $240 \mathrm{~kg} \mathrm{~N} \mathrm{ha}^{-1}$, increased by 62 to $72 \%, 56$ to $67 \%$, and 80 to $93 \%$, respectively, with the alternate wetting and drying irrigation system. This irrigation system was also tested in other countries growing paddy like India and the Philippines, which confirmed the water conservation potential of the AWD irrigation system without compromising on the yields [50]. Carrijo et al., recently found that mild-AWD can conserve water by $23.4 \%$ compared to the continuous flooding methods without a considerable loss in the yields [51]. However, if the rice crop undergoes a severe AWD (soils are dried significantly) the loss in the final yield was over $20 \%$ compared to the continuous flooding method [51]. Similarly, a study reported that alternate 
wetting and drying irrigation showed a higher paddy yield (8516-8346 $\left.\mathrm{kg} \mathrm{ha}^{-1}\right)$ in two years of experimentation as compared to controlled irrigation treatments (6532-7868 $\left.\mathrm{kg} \mathrm{ha}^{-1}\right)$ [52].

Furthermore, various researchers have shown that global warming can have a negative impact on the yields of paddy produced around the world. Over the past century, the average global temperatures have increased by 0.5 to $0.6{ }^{\circ} \mathrm{C}$ [53]. The increase in temperature has resulted in increased respiration in the plant and a subsequent increase in carbon metabolism and a decrease in the yield of paddy [54]. The higher temperatures can also cause the flowers of the paddy to become sterile, disrupting the reproduction process. Recently, the International Food Policy Research Institute (IFPRI) reported that climate change could reduce the paddy yield by 10 to $15 \%$, which can result in a rise in market price by 32 to 37\% [55,56]. Using historic data from 1999 to 2007, the ORYZA 2000 model predicted for Malaysia that a $2{ }^{\circ} \mathrm{C}$ temperature increase could reduce paddy yields by $0.36 \mathrm{t} \mathrm{ha}^{-1}$, which would result in a huge economic loss [57]. Matthews et al., simulated the impact of increased atmospheric carbon dioxide on the productivity of rice in various parts of Asia and found that on average the yields will go down by $4 \%$ [58]. Though, there are areas where the yields would rise due to the increased global temperatures (especially in regions with cooler climate) leading to double-cropping, this would not be sufficient to compensate for the overall loss in yields in various parts of Asia, which grows the majority of rice in the world [58]. The study suggested using shorter-maturing varieties with shorter ripening periods to maintain the yields.

There are numerous studies that suggest that global warming will increase the yield of rice from $2.9-34 \%$ depending on highly optimistic scenarios primarily due to warming in the night and production moving to areas that have a cooler climate now that would heat up as a result of climate change in the 2050s and 2080s [59-61]. However, these studies do not necessarily consider the socio-economic consequences in the regions that are currently growing rice and available strategies for these farmers to cope with the loss of rice production. Furthermore, despite a slight increase in production, various studies agree that in the long-run the yields will fall drastically as the global temperature increases by the end of the century $[58,62,63]$. If no effective strategies to tackle reduced yields are implemented soon, global warming will cause a shortage of food, thereby resulting in food insecurity for future generations.

\subsection{Millet}

Millet crops have a deep-rooted system that is beneficial and can utilize the residual nitrogen, phosphorus, and potassium in the soil. Hence, this deep-root system does not require a high quantity of fertilizer in comparison with other crops. Pearl millet (Pennisetum glaucum) accounts for more than $50 \%$ of the global millet production [64]. Compared to traditional cereal crops, pearl millet requires lower amounts of resources for its growth and can grow in adverse conditions (e.g., water and fertilizer shortage) due to its physiological characteristics [24,65]. In one field study, four pearl millet genotypes $(2304$, LHB08, 606A1*2304, and 707A1*4280) were grown using four different quantities of nitrogen: 0 , 40,80 , and $120 \mathrm{~kg} \mathrm{ha}^{-1}$ [66]. The results from this study showed that the application of $\mathrm{N}$ fertilizer in varying quantities does not have any significant effect on the head length, plant (dry) weight, and the final yield of pearl millet. However, another study reported that significant differences were found in the dry forage yields of pearl millet treated with different levels of $\mathrm{N}$ fertilization during the growth period (0-300 $\left.\mathrm{kg} \mathrm{ha}^{-1}\right)$ [67]. These discrepancies in the data reported warrants further investigation into how the application of $\mathrm{N}$ fertilizers would impact the millet yields.

Moreover, millet is one of the most drought-resistant crops due to its strong root system, which allows them to grow in areas that experience frequent periods of dry weather [68]. Many studies showed that the yield of millets in dry areas increased with the increasing temperature. A study reported an average annual increment of $30 \mathrm{~kg} \mathrm{ha}^{-1}$ to $121 \mathrm{~kg} \mathrm{ha}^{-1}$ in the yields of millet as the temperature rose in three different cities in China (Xifeng, Anding, and Ganzhou). They recommend the expansion of millet plantations in the province due to the rising temperature [69]. Furthermore, a study simulated the impact of temperature change on the yield of millet through a modified 
CSM-CERES-Pearl millet simulation model [64]. The results found that the millet yield increased by $6 \%$ after drought (lower limit of soil water availability) and $8 \%$ after heat simulation (increased from $27^{\circ} \mathrm{C}$ to $29^{\circ} \mathrm{C}$ ). Drought and heat tolerance together showed an increase in millet yield which amounts to $14 \%$ under climate change. Furthermore, millets also possess the ability to grow in hilly terrain and mountainous regions where cultivation of other cereals is difficult [70]. This shows that millets possess the potential to be a vital crop that could grow with limited nitrogen input in drought, high-temperature and hilly regions around the world. This is one crop that clearly has the potential to reduce the carbon footprint as it has the least global warming potential, and at the same time is resistant to the global warming effects such as increased frequency in droughts and increased average temperatures.

\subsection{Maize}

Modeling of crop yields indicates that the maize yield in Malawi will decrease $14 \%$ by mid-century, and $33 \%$ by the century's end because of climate change [71]. Similarly, in the northeast region of China, global warming modeling forecasted that the extreme temperature increase (where temperature increases by $1.32{ }^{\circ} \mathrm{C}$ ) would lead to a decrease in maize production by $\sim 35 \%$ in 2030 as compared to productivity in 2008 [72]. In the United States, global warming has resulted in an average $2.5 \%$ decrease in maize yield in the period from 1970 to 1999, and precipitation modeling reported that by the 2050s, corn yields are projected to decrease further by 20 to $50 \%$ depending on the current emission scenarios [73]. Water supply is also a vital factor for maize production. Studies revealed that from 1999 to 2002 , the average yield of maize grown under irrigation $\left(12.44 \mathrm{t} \mathrm{ha}^{-1}\right)$ was $16.5 \%$ higher than when cultivated under non-irrigated condition (10.68 $\mathrm{t} \mathrm{ha}^{-1}$ ) [74]. The yields of maize grown under two irrigation systems, raised bed and drip irrigation systems, were compared [75]. The results showed that compared to the drip irrigation system, the raised bed irrigation system was beneficial for increasing the plant height, biological yield, and grain yield by $1 \%, 5 \%$, and $21 \%$, respectively. Researchers have also evaluated the changes in the maize yields in Africa with a $2{ }^{\circ} \mathrm{C}$ raise in temperature and a $20 \%$ reduction in the precipitation. They reported that the yields reduced by about $10 \%$ under these conditions [76]. Lobell et al., further used the historical data in understanding the role of moisture on the final yields of maize. They reported that a loss of $1 \%$ and $1.7 \%$ was observed in the final yield of maize for each day the crop spends at a temperature over $30{ }^{\circ} \mathrm{C}$ under rain-fed conditions and drought conditions. They showed that moisture plays a vital role in maize's ability to cope with the high temperatures that will be caused due to global warming [77]. A comprehensive study on changes in maize productivity was published in 2014 in which the yield sensitivity was investigated based on temperature and atmospheric $\mathrm{CO}_{2}$. A total of 23 models were tested in four locations (France, USA, Brazil, and Tanzania) in four different continents. The results showed a strong correlation between the temperature and yields, where the yields reduced by about $0.5 \mathrm{t}$ ha ${ }^{-1}$ per $1^{\circ} \mathrm{C}$ raise in temperature. However, the study showed that the yields increased slightly (with large uncertainty) when the atmospheric $\mathrm{CO}_{2}$ levels doubled from $360 \mathrm{ppm}$ to $720 \mathrm{ppm}$. The study concluded that if innovative management techniques are not implemented to control the increasing temperature, drastic yield loses in maize are possible in various parts of the world. Furthermore, these losses cannot be counteracted by the projected raise in yields due to the raise in atmospheric $\mathrm{CO}_{2}$ [78].

Nitrogen plays a major role in the cultivating stages of maize, directly influencing plant height, grain yield, and kernel quality. A high yielding cultivar of maize (BH 661) was fertilized with five different levels of nitrogen: $0,23,46,69$, and $92 \mathrm{~kg} \mathrm{~N}$ ha $^{-1}$ [29]. The results showed that the number of leaves per plant, plant height, ear length, kernel quality, number of rows per ear, and grain yield increased with increasing rates of nitrogen fertilization. The number of kernels per ear and ear length were highest with $92 \mathrm{~kg} \mathrm{~N} \mathrm{ha}^{-1}$ compared to the control group and other treatments. In a similar study, maize cultivar BH-660 was cultivated using five levels of Nitrogen $\left(0,46,92,138\right.$, and $\left.184 \mathrm{~kg} \mathrm{ha}^{-1}\right)$ and five levels of Phosphorus $\left(0,23,46,69\right.$, and $\left.92 \mathrm{~kg} \mathrm{ha}^{-1}\right)$ [79]. The results showed that the combination of Nitrogen and Phosphorus significantly increased the grain production and biomass yield of maize. 
The highest grain $\left(5497.5 \mathrm{~kg} \mathrm{ha}^{-1}\right)$ and biomass yields $\left(16,521 \mathrm{~kg} \mathrm{ha}^{-1}\right)$ were recorded when the maximum level of $\mathrm{N} / \mathrm{P}\left(184 / 92 \mathrm{~kg} \mathrm{ha}^{-1}\right)$ was applied to the crop.

\subsection{Wheat}

Global climate changes and extreme weather events will have a huge impact on the production of wheat, one of the most widely consumed cereals. In France, winter wheat yields were analyzed using a modelling approach based on historical yield and gridded weather data available from 1950 to 2015. The model predicted that due to climate change, the wheat yield would be reduced by 3.5 to $12.9 \%$ in the medium term from 2037-2065, and it further predicted that winter wheat productions would decrease by 14.6 to $17.2 \%$ by the end of the century [80]. In China, researchers reported that wheat production rates would be reduced by 3 to $10 \%$ due to a $1{ }^{\circ} \mathrm{C}$ increase in temperature during the growing period based on the historical data between 1970-2000. The same study also reported that the increase in temperature over the last two decades would have resulted in the yields dropping by $4.5 \%$, if not for the increased use of resources (like irrigation, fertilizers etc.,) in growing the crops [10]. Experimental observations on wheat yields between 1981-2009 across China showed a wide variation in the productivity of wheat in different climactic regions. They found that the wheat yields in Northern China rose by $1-13 \%$ while a reduction of $1 \%$ to $10 \%$ was observed in Southern China [81]. In Turkey, a wheat yield prediction model with a long term forecast to 2100 was used to estimate yields based on regional panel data (NUTS2), and the results showed that the wheat production would decline by $8 \%$ to $23 \%$ by the end of 2100 [82]. These models predicted that as the temperature increased on the earth's surface, the soil would become drier leading to lower yields. This could drive up the price of wheat on the markets as it is the main ingredient in many food products around the world.

Water is one of the most important factors for proper growth, balanced development, and high yields of wheat. Two cultivars of winter wheat (Baviaans and 14SAWYT306) were cultivated with three irrigation durations or schedules with the control case having no irrigation. The three schedules were irrigation up to development of the stem extension, irrigation from stem extension up to physiological maturity, and irrigation throughout the growth of the crop [32]. The results showed that irrigation treatments significantly increased grain yield compared to no irrigation treatment for both cultivars. Compared with no irrigation, irrigation throughout the growth period increased the number of tillers, number of grains per spike, grain yield, harvest index, and grain protein by $20.58 \%, 26.07 \%, 42.72 \%$, $16.71 \%$, and $3.31 \%$, respectively.

\section{Food Security}

Food security is comprised of food availability, food accessibility, food utilization, and food systems stability [83]. Climate change is a potential threat to food security as it is capable of decreasing crop yields, and intensifying competition over scarce resources. As shown in Figure 1, more and more countries are facing food insecurity as the climate is changing. It was predicted that by the end of 2017, Mongolia, Mauritania, Niger, Chad, Somalia, and Namibia would be facing a high level of food insecurity (Figure 1A), which appears to have been true. According to the World Food Programme, countries such as India, Zambia, Myanmar, Egypt, and Botswana will join the list of countries facing adverse food insecurity issues by the end of the 2050s (Figure 1B). Furthermore, by the end of the 2080s, most of the African and Asian countries will be facing a high level of food insecurity due to increasing temperatures and depleting resources (Figure 1C) [83]. 

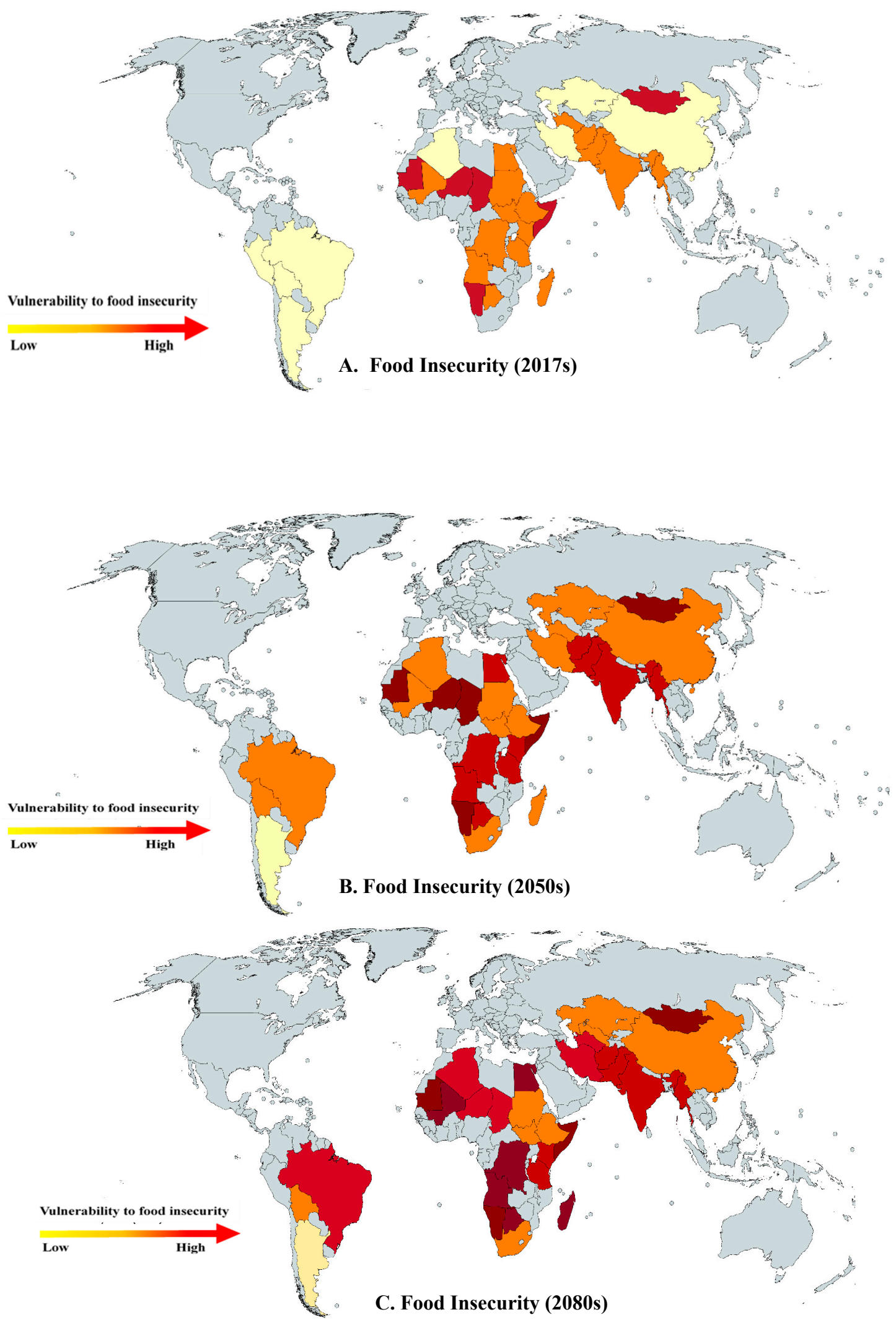

Figure 1. Food security scenarios due to climate change in regions where cultivation of millet can be easily adopted (A) 2017, (B) 2050s (C) 2080s (Source: World Food Program-WFP). 


\subsection{Food Availability and Accessibility}

Food availability refers to the total amount of food having an acceptable quality available for consumption either through domestic production or through importation. This is one of the primary factors for evaluating food security [83]. Currently, climate change has a negative influence on food security as various predictions indicate a significant decrease in the productivity of different crops [84]. Many studies found that climate change can reduce the yield of wheat by 3.5 to $12.9 \%$ [80], of maize by 34.6 to $35.4 \%$ [72], and of paddy by 10 to $15 \%$ [55,56]. Also, the global growth rate of the human population is estimated to be $1.1 \%$ per year and the total population is anticipated to grow from 7.6 billion in 2017 to 9.8 billion by 2050 [1]. The decrease of crop yield due to global warming will make it difficult to feed this rapid explosion in population, which can lead to extremely scarce availability of food in the future, thereby jeopardizing food security and safety.

Food accessibility refers to the ability of individuals, communities and countries to purchase quality food in sufficient quantities. Many factors affect the food accessibility such as food price, educational background, and property rights [83]. Recent research reported that the negative effect of climate change on food production resulted in increases in food prices by as much as 20\% [85]. Various predictions have shown that by the end of the 2050s, the market prices of corn will rise by 42 to $131 \%$ due to the predicted increase in global warming and population growth. The market prices of rice are predicted to rise, between $11 \%$ to $78 \%$, due to yield reduction caused by climate change $[55,86,87]$.

\subsection{Food Utilization and Food Systems Stability}

Food utilization refers to the capacity of an individual or a household to consume and benefit from food [88]. The utilization component of food security is generally related to the nutritional aspects of the food consumed. If food sources are not able to provide a balanced and nutritious diet, the implications on the health and productivity of the population could be significant. Many studies stated that climate change reduced the food quality including their nutritional value. A report found that the proportion of total soluble sugars and starch present in soybean decreased because of an increase in the temperature from $28 / 18{ }^{\circ} \mathrm{C}$ to $44 / 34{ }^{\circ} \mathrm{C}$ (day/night) during cultivation [89]. In the case of wheat, a 2 to $4{ }^{\circ} \mathrm{C}$ increase can influence the starch content, granular size and gelatinization of the grain [90]. On the other hand, climate change can also lead to mutation and development of new pests, pathogens, and weeds which could affect the food chain, human health, crop yield, and quality [91].

The term 'food systems' deals with nutrition, human health, community, economic development and agriculture. Generally, it includes growing, harvesting, processing, packaging, transporting, marketing, consumption, and disposal of food [92]. Global warming and the current trend of climate change have the potential to push our food systems to the brink of becoming unsustainable by increasing food price [86]. For poor people, especially in developing countries, food security can be easily affected by fluctuations in price because a considerable proportion of their income is spent on foods. Maintaining the stability of food systems is challenging, especially in the context of global warming and climate change [93].

\section{Potential Strategies to Increase Cereal Crops Production}

Climate change has the potential to influence the cereal yield directly by heat and water stresses but can also indirectly impact the fertilizer supply, diseases, and pests [14]. Researchers agree that global warming, due to release of carbon dioxide, is an irreversible trend over a period of hundreds of years and can have long-term implications on the planet [94]. For now, improving the yields of various cereal crops and reducing global food losses are essential to keeping pace with population growth and to mitigate the influence of climate change. Possible technical solutions for achieving improved crop yields and countering the effects of climate change are briefly discussed below. 


\subsection{Breeding}

The average temperatures around the globe are estimated to increase by $2.5-4.5^{\circ} \mathrm{C}$ by the end of this century [6,7]. The maintenance of an appropriate temperature during the growth period is vital for cereal crops in different stages of cultivation since most of the cereal crops are highly sensitive to environmental and climatic variations. For example, high temperatures can reduce pollen viability and result in reduced kernel numbers and ultimately the yield during the heading and flowering periods [95].

Traditionally, breeding is used to improve the yield of crops rather than their tolerance to high temperatures. However, there is an increasing need to breed new varieties of crops that can withstand extreme weather events and increasing annual temperatures with stable production rates [96]. Studies have been carried out on exploiting and extending the existing genetic variability to develop new heat-tolerant and high-yielding crop genotypes. For example, new varieties of cowpeas have been developed that have higher average grain yields when grown under high temperatures. This was an improvement from the traditional variety of cowpea whose yield reduced drastically when the night-temperature rose above $20^{\circ} \mathrm{C}$ [97]. Also, a recurrent selection method using ancestor T. tauschii as a gene donor, has been successfully used to increase grain filling and produce larger grains in BC1F6 wheat plants [98]. Furthermore, a gene related to heat tolerance present in potatoes was selected through three-cycle recurrent selection breeding, which led to an increase of up to $37.8 \%$ in yield. The breeding technique in this case was used to develop varieties that can give better production rates in tropical climate using potato varieties native to Europe [99]. In other studies, over-expression of glycerol-3-phosphate acyltransferase was found to result in increased saturation of the thylakoid membrane lipids in transgenic tobacco plants. These plants showed faster recovery rates after heat stress compared to wild plants [100]. This showed that glycerol-3-phosphate acyltransferase plays a major role in improving the heat resistance of plants. It is possible to also achieve over-expression of enzymes related to glycerol-3-phosphate acyltransferase at higher levels in cereal crops (e.g., wheat, maize, paddy) through molecular breeding, which can possiby increase the heat tolerance.

\subsection{Irrigation and Fertilizer Efficiency}

Application of water and fertilizer plays a vital role in determining the yields of various crops during different stages of cultivation. The yield of crops increased only within a certain range of increase in water and fertilizer application. However, some developing countries (e.g., China, India, Algeria, Egypt, Iran, Mexico, and Pakistan) are facing issues with water scarcity due to climate change, population explosion, excessive agricultural activities, and industry usage [101]. For example, in China, the wetlands have shrunk by $9 \%$, namely 340,000 square kilometers since 2003 [102]. Thus, improving the irrigation efficiency must be considered a priority as part of a strategy for the development of sustainable agriculture practices and increasing production of various crops. The International Food Policy Research Institute (IFPRI) reported that increasing the irrigation efficiency could increase the crop yields by $21 \%[55,103]$. An evaluation of the efficiency of water use in California for different cultivation techniques [104] reported that efficiency of water use was 60 to $85 \%$ in surface irrigation, 70 to $90 \%$ for sprinkler irrigation, and 88 to $90 \%$ for drip irrigation. Thus using a drip irrigation system could effectively control water usage and help improve yields and reduce the quantity of water usage by more than $50 \%$ [105].

Furthermore, the use of fertilizer is another vital factor that directly impacts crop production. Over the past few decades, an estimated $30-60 \%$ increase in crop production was because of the use of fertilizers [105]. Currently, the usage of fertilizer is increasing in both developed and developing countries. Food and Agriculture Organization (FAO) reported that fertilizer application reached $186,900,000$ tonnes in 2014 , up by $2.0 \%$ compared to 2013 . World demand for fertilizers is estimated to be growing at $1.8 \%$ per annum from 2014 to 2018. However, long-term excessive application of fertilizers has been shown to have a negative effect on the soil and on the quality of cereal crop. Several studies have shown that over-fertilization can lead to soil acidification $[15,106]$. Furthermore, 
nitrogen leaching and ammonia volatilization also contribute to environmental issues in areas where urea and nitrogen-fertilizers are applied. Similarly, a study reported that the soil $\mathrm{pH}$ declined to 4.3 after 13-years of production in Shouguang and Shandong provinces in China, which potentially can lead to reduced crop yields and quality [107]. Therefore, an emphasis has to be placed on using fertilizers at appropriate levels, which can save resources and avoid environmental pollution.

\subsection{Increasing the Cultivation Area of Tolerant Cereal Crops}

The aforementioned millets, and especially pearl millet, are considered to be the most drought-tolerant among the major cereal grain crops (e.g., wheat, maize, paddy). As studies have shown, the cultivation of rice will move to the regions that are warming-up (traditionally temperate zones) as global temperatures increase in Asian countries like China, and India. To compensate for the loss of the rice crop, Millets could be grown in the resulting drylands as a result of their strong root system, which helps them to tolerate water stresses [68]. Moreover, millets need little to no fertilizers. Millet is a C4 crop, meaning it has the ability to fix carbon at a lower transpiration rate compared to other cereal crops [24]. Millets can adapt to various soil environments (sandy, acidic and alkaline soils, and acidic soils) with a wide range of soil $\mathrm{pH}$ between 4.5 to 8.0 [26]. Apart from the ability to fix carbon, research has showed that the $\mathrm{C} 4$ crops (including maize) have various other advantages. Firstly, reports have shown that the projected rate of yield decline in $\mathrm{C} 4$ crops is much smaller compared to C3 crops like rice and wheat. This is primarily due ot their tolerance towards low moisture atmosphere. The water use efficiency is 150-400\% higher in C4 crops compared to C3 crops [108,109]. Secondly, C4 crops have a lower photo-respiration under increased $\mathrm{CO}_{2}$ and temperature in the atmosphere, which are predicted to be the result of global warming [109]. Some modeling studies have suggested that by using improved and water-efficient irrigation technologies in the future, the yields of C4 crops can be increased by up to $38 \%$ under the predicted climatic conditions in few areas, whereas the yields of C3 crops will have no significant change $[109,110]$.

Though there are various C4 crops, millets are more environment-friendly because they release less greenhouse gases when compared to other cereal crops and climate change effects appear to have less influence on millet yields. Sorghum is another drought-tolerant crop, which is mostly attributed to its dense and prolific root system, ability to maintain relatively high levels of stomatal conductance, maintenance of internal tissue water potential through osmotic adjustment, and phenological plasticity [111]. Furthermore, millet is already grown in the various tropical countries of Asia, Africa, and to a lesser extent South America (Figure 1). Hence, by educating the local growers, introducing policy changes and technological interventions to reduce the work-load on farmers could ultimately increase the production of millets in these areas. It is pertinent to concentrate in these regions as the majority of the world population now lives in tropical climates where climate change can directly impact the crop yields, production rates, hydrological balance, temperature, and soil quality [112,113]. Thus, increasing the area of land used to grow tolerant cereal crops (e.g., millet and sorghum) is a vital strategy for reducing the influence of climate change, issues of water shortage, and food security.

\section{Conclusions}

This review summarizes the growing requirements of different cereal crops and influences of climate change on the yields of various cereal crops around the world. Breeding and irrigation techniques were presented as solutions to address these issues and challenges caused by global warming. Climate change and especially the increase in ambient temperatures will reduce the yields of major cereal crops. Hence, to achieve our goals of food security, we need to emphasize the use and production of food crops that can withstand the on-going changes to the climate to replace or be an alternative to the current major cereal crops, especially in the arid and semi-arid regions around the globe that are at a greater risk of food insecurity. Millet is one such crop that is tolerant to increasing temperatures and has the ability to grow in subpar quality soils. Furthermore, millet production can help to mitigate climate change since it emits less greenhouse gases than other cereal crops, and has 
less environmental impact since it requires little or no input of fertilizer and water while growing on marginal land. Therefore, efforts should be made to encourage farmers to grow these crops and to increase their market value, especially in developing countries. Researchers and growers should develop diversification stratergies based on local conditions. This should be part of the strategy for achieving food security within the context of climate change and a rapidly increasing population. Furthermore, it has to be noted that an holistic approach is required in tackling food insecurity issue as there is no single solution that can solve the issue.

Acknowledgments: The authors are grateful to China Scholarship Council (CSC) for its financial support. The authors also acknowledge funding from the International Development Research Centre (IDRC) and Global Affairs Canada (GAC) for executing this project.

Conflicts of Interest: The authors declare no conflict of interest.

\section{References}

1. Godfray, H.C.J.; Beddington, J.R.; Crute, I.R.; Haddad, L.; Lawrence, D.; Muir, J.F.; Pretty, J.; Robinson, S.; Thomas, S.M.; Toulmin, C. Food security: The challenge of feeding 9 billion people. Science 2010, 327, 812-818. [CrossRef] [PubMed]

2. Ray, D.K.; Mueller, N.D.; West, P.C.; Foley, J.A. Yield trends are insufficient to double global crop production by 2050. PLoS ONE 2013, 8, e66428. [CrossRef] [PubMed]

3. Hawkesford, M.J.; Araus, J.L.; Park, R.; Calderini, D.; Miralles, D.; Shen, T.; Zhang, J.; Parry, M.A. Prospects of doubling global wheat yields. Food Energy Secur. 2013, 2, 34-48. [CrossRef]

4. Tripathi, A.; Tripathi, D.K.; Chauhan, D.; Kumar, N.; Singh, G. Paradigms of climate change impacts on some major food sources of the world: A review on current knowledge and future prospects. Agric. Ecosyst. Environ. 2016, 216, 356-373. [CrossRef]

5. Howden, S.M.; Soussana, J.-F.; Tubiello, F.N.; Chhetri, N.; Dunlop, M.; Meinke, H. Adapting agriculture to climate change. Proc. Natl. Acad. Sci. USA 2007, 104, 19691-19696. [CrossRef] [PubMed]

6. Solomon, S. Climate Change 2007-The Physical Science Basis: Working Group I Contribution to the Fourth Assessment Report of the IPCC; Cambridge University Press: Cambridge, UK, 2007; Volume 4.

7. $\quad$ Bernstein, L.; Bosch, P.; Canziani, O.; Chen, Z.; Christ, R.; Riahi, K. IPCC, 2007: Climate Change 2007: Synthesis Report; IPCC: Geneva, Switzerland, 2008.

8. Asseng, S.; Foster, I.; Turner, N.C. The impact of temperature variability on wheat yields. Glob. Chang. Biol. 2011, 17, 997-1012. [CrossRef]

9. Högy, P.; Fangmeier, A. Effects of elevated atmospheric $\mathrm{CO}_{2}$ on grain quality of wheat. J. Cereal Sci. 2008, 48, 580-591. [CrossRef]

10. You, L.; Rosegrant, M.W.; Wood, S.; Sun, D. Impact of growing season temperature on wheat productivity in China. Agric. For. Meteorol. 2009, 149, 1009-1014. [CrossRef]

11. Jain, N.; Arora, P.; Tomer, R.; Mishra, S.V.; Bhatia, A.; Pathak, H.; Chakraborty, D.; Kumar, V.; Dubey, D.; Harit, R. Greenhouse gases emission from soils under major crops in northwest India. Sci. Total Environ. 2016, 542, 551-561. [CrossRef] [PubMed]

12. Jain, R.; Bal, S. Properties of pearl millet. J. Agric. Eng. Res. 1997, 66, 85-91. [CrossRef]

13. Yao, F.; Huang, J.; Cui, K.; Nie, L.; Xiang, J.; Liu, X.; Wu, W.; Chen, M.; Peng, S. Agronomic performance of high-yielding rice variety grown under alternate wetting and drying irrigation. Field Crops Res. 2012, 126, 16-22. [CrossRef]

14. Porter, J.R.; Xie, L.; Challinor, A.J.; Cochrane, K.; Howden, S.M.; Iqbal, M.M.; Lobell, D.B.; Travasso, M.I.; Netra Chhetri, N.C.; Garrett, K. Food Security and Food Production Systems; IPCC: Geneva, Switzerland, 2014.

15. Faostat, F.; Production, A.C. Food and Agriculture Organization of the United Nations, 2016; FAO: Rome, Italy, 2017.

16. Lal, R. Restoring soil and water resources and mitigating climate change in India by judicious management of agricultural and urban wastes. J. Indian Soc. Soil Sci. 2017, 65, 105-117. [CrossRef]

17. Mo, X.-G.; Hu, S.; Lin, Z.-H.; Liu, S.-X.; Xia, J. Impacts of climate change on agricultural water resources and adaptation on the north China plain. Adv. Clim. Chang. Res. 2017, 8, 93-98. [CrossRef] 
18. Coats, B. Global rice production. In Rice Origin, History, Technology and Production; Wiley: Hoboken, NJ, USA, 2003; pp. 247-470.

19. Guo, Z.; Chai, M.; Zhan, Z.; Chen, Z. Spatiotemporal Variation of Soil PH in the Past 30 Years of Guangdong Province, China. In Proceedings of the 2011 19th International Conference on Geoinformatics, Shanghai, China, 24-26 June 2011; IEEE: Piscataway, NJ, USA, 2011; pp. 1-5.

20. Santos, E.S.; Abreu, M.M.; Magalhães, M.C.; Viegas, W.; Amâncio, S.; Cordovil, C. Nutrients Levels in Paddy Soils and Flood Waters from Tagus-Sado Basin: The Impact of Farming System. In Proceedings of the 19th EGU General Assembly, EGU2017, Vienna, Austria, 23-28 April 2017; p. 17129.

21. Lamers, M.; Anyusheva, M.; La, N.; Nguyen, V.V.; Streck, T. Pesticide pollution in surface-and groundwater by paddy rice cultivation: A case study from northern Vietnam. Clean-Soil Air Water 2011, 39, 356-361. [CrossRef]

22. Amadou, I.; Gounga, M.E.; Le, G.-W. Millets: Nutritional composition, some health benefits and processing-A review. Emir. J. Food Agric. 2013, 25, 501-508. [CrossRef]

23. Wen, Y.; Liu, J.; Meng, X.; Zhang, D.; Zhao, G. Characterization of proso millet starches from different geographical origins of China. Food Sci. Biotechnol. 2014, 23, 1371-1377. [CrossRef]

24. Habiyaremye, C.; Matanguihan, J.B.; D’Alpoim Guedes, J.; Ganjyal, G.M.; Whiteman, M.R.; Kidwell, K.K.; Murphy, K.M. Proso millet (Panicum miliaceum L.) and its potential for cultivation in the Pacific Northwest, US: A review. Front. Plant Sci. 2017, 7, 1961. [CrossRef] [PubMed]

25. Goron, T.L.; Raizada, M.N. Genetic diversity and genomic resources available for the small millet crops to accelerate a new green revolution. Front. Plant Sci. 2015, 6, 157. [CrossRef] [PubMed]

26. Changmei, S.; Dorothy, J. Millet-the frugal grain. Int. J. Sci. Res. Rev. 2014, 3, 75-90.

27. Piperno, D.R.; Flannery, K.V. The earliest archaeological maize (Zea mays L.) from highland Mexico: New accelerator mass spectrometry dates and their implications. Proc. Natl. Acad. Sci. USA 2001, 98, 2101-2103. [CrossRef] [PubMed]

28. Zamir, M.; Yasin, G.; Javeed, H.; Ahmad, A.; Tanveer, A.; Yaseen, M. Effect of different sowing techniques and mulches on the growth and yield behavior of spring planted maize (Zea mays L.). Cercetari Agronomice in Moldova 2013, 46, 77-82. [CrossRef]

29. Woldesenbet, M.; Haileyesus, A. Effect of nitrogen fertilizer on growth, yield and yield components of maize (Zea mays L.) in Decha district, Southwestern Ethiopia. Intl. J. Res. Granthaalayah 2016, 4, 95-100.

30. Yin, G.; Gu, J.; Zhang, F.; Hao, L.; Cong, P.; Liu, Z. Maize yield response to water supply and fertilizer input in a semi-arid environment of northeast china. PLoS ONE 2014, 9, e86099. [CrossRef] [PubMed]

31. Anon. Fertilizers for Corn. Available online: https://fieldcrops.cals.cornell.edu/corn/fertilizers-corn (accessed on 24 April 2018).

32. Ngwako, S.; Mashiqa, P. The effect of irrigation on the growth and yield of winter wheat (Triticum aestivum L.) cultivars. Int. J. Agric. Crop Sci. 2013, 5, 976-982.

33. Hergert, G.W.; Shaver, T.M. Fertilizing Winter Wheat; UNL-West Central Research and Extension Center: North Plate, NE, USA, 2009; p. 69101.

34. Acevedo, E.; Silva, P.; Silva, H. Wheat growth and physiology. In Bread Wheat; Plant Production and Protection Series (FAO); FAO: Rome, Italy, 2002.

35. Rajaniemi, M.; Mikkola, H.; Ahokas, J. Greenhouse gas emissions from oats, barley, wheat and rye production. Agron. Res. 2011, 9, 189-195.

36. Smit, B.; Skinner, M.W. Adaptation options in agriculture to climate change: A typology. Mitig. Adapt. Strat. Glob. Chang. 2002, 7, 85-114. [CrossRef]

37. Wang, Y.; Hu, C.; Ming, H.; Zhang, Y.; Li, X.; Dong, W.; Oenema, O. Concentration profiles of $\mathrm{CH}_{4}, \mathrm{CO}_{2}$ and $\mathrm{N}_{2} \mathrm{O}$ in soils of a wheat-maize rotation ecosystem in North China plain, measured weekly over a whole year. Agric. Ecosyst. Environ. 2013, 164, 260-272. [CrossRef]

38. Cole, C.; Duxbury, J.; Freney, J.; Heinemeyer, O.; Minami, K.; Mosier, A.; Paustian, K.; Rosenberg, N.; Sampson, N.; Sauerbeck, D. Global estimates of potential mitigation of greenhouse gas emissions by agriculture. Nutr. Cycl. Agroecosyst. 1997, 49, 221-228. [CrossRef]

39. Intergovernmental Panel on Climate Change (IPCC). Climate Change 2013: The Physical Science Basis. Contribution of Working Group I to the Fifth Assessment Report of the Intergovernmental Panel on Climate Change; Stocker, T.F., Qin, D., Plattner, G.-K., Tignor, M., Allen, S.K., Boschung, J., Nauels, A., Xia, Y., Bex, V., Midgley, P.M., Eds.; Cambridge University Press: Cambridge, UK; New York, NY, USA, 2013. 
40. Intergovernmental Panel on Climate Change (IPCC). Climate Change 2001: The Scientific Basis. Contribution of Working Group I to the Third Assessment Report of the Intergovernmental Panel on Climate Change; Cambridge University Press: Cambridge, UK; New York, NY, USA, 2011; p. 881.

41. Shang, Q.; Yang, X.; Gao, C.; Wu, P.; Liu, J.; Xu, Y.; Shen, Q.; Zou, J.; Guo, S. Net annual global warming potential and greenhouse gas intensity in Chinese double rice-cropping systems: A 3-year field measurement in long-term fertilizer experiments. Glob. Chang. Biol. 2011, 17, 2196-2210. [CrossRef]

42. Adviento-Borbe, M.; Haddix, M.; Binder, D.; Walters, D.; Dobermann, A. Soil greenhouse gas fluxes and global warming potential in four high-yielding maize systems. Glob. Chang. Biol. 2007, 13, 1972-1988. [CrossRef]

43. Bhatia, A.; Pathak, H.; Jain, N.; Singh, P.; Singh, A. Global warming potential of manure amended soils under rice-wheat system in the indo-gangetic plains. Atmos. Environ. 2005, 39, 6976-6984. [CrossRef]

44. Das, S.; Adhya, T.K. Effect of combine application of organic manure and inorganic fertilizer on methane and nitrous oxide emissions from a tropical flooded soil planted to rice. Geoderma 2014, 213, 185-192. [CrossRef]

45. Mosier, A.R.; Halvorson, A.D.; Reule, C.A.; Liu, X.J. Net global warming potential and greenhouse gas intensity in irrigated cropping systems in northeastern colorado. J. Environ. Qual. 2006, 35, 1584-1598. [CrossRef] [PubMed]

46. Tuomisto, H.; Hodge, I.; Riordan, P.; Macdonald, D. Comparing global warming potential, energy use and land use of organic, conventional and integrated winter wheat production. Ann. Appl. Biol. 2012, 161, 116-126. [CrossRef]

47. Dendooven, L.; Patino-Zúniga, L.; Verhulst, N.; Luna-Guido, M.; Marsch, R.; Govaerts, B. Global warming potential of agricultural systems with contrasting tillage and residue management in the central highlands of mexico. Agric. Ecosyst. Environ. 2012, 152, 50-58. [CrossRef]

48. Bhatia, A.; Pathak, H.; Aggarwal, P.K.; Jain, N. Trade-off between productivity enhancement and global warming potential of rice and wheat in India. Nutr. Cycl. Agroecosyst. 2010, 86, 413-424. [CrossRef]

49. Laratte, B.; Guillaume, B.; Kim, J.; Birregah, B. Modeling cumulative effects in life cycle assessment: The case of fertilizer in wheat production contributing to the global warming potential. Sci. Total Environ. 2014, 481, 588-595. [CrossRef] [PubMed]

50. Ye, Y.; Liang, X.; Chen, Y.; Liu, J.; Gu, J.; Guo, R.; Li, L. Alternate wetting and drying irrigation and controlled-release nitrogen fertilizer in late-season rice. Effects on dry matter accumulation, yield, water and nitrogen use. Field Crops Res. 2013, 144, 212-224. [CrossRef]

51. Carrijo, D.R.; Lundy, M.E.; Linquist, B.A. Rice yields and water use under alternate wetting and drying irrigation: A meta-analysis. Field Crops Res. 2017, 203, 173-180. [CrossRef]

52. Shao, G.-C.; Deng, S.; Liu, N.; Yu, S.-E.; Wang, M.-H.; She, D.-L. Effects of controlled irrigation and drainage on growth, grain yield and water use in paddy rice. Eur. J. Agron. 2014, 53, 1-9. [CrossRef]

53. Hansen, J.; Ruedy, R.; Sato, M.; Lo, K. Global surface temperature change. Rev. Geophys. 2010, 48, RG4004. [CrossRef]

54. Zhao, X.; Fitzgerald, M. Climate change: Implications for the yield of edible rice. PLoS ONE 2013, 8, e66218. [CrossRef] [PubMed]

55. Nelson, G.C.; Rosegrant, M.W.; Koo, J.; Robertson, R.; Sulser, T.; Zhu, T.; Ringler, C.; Msangi, S.; Palazzo, A.; Batka, M. Climate Change: Impact on Agriculture and Costs of Adaptation; IFPRI: Washington, DC, USA, 2009; Volume 21.

56. Li, M. Climate Change to Adversely Impact Grain Production in China by 2030; IFPRI: Washington, DC, USA, 2018; Volume 2018.

57. Vaghefi, N.; Shamsudin, M.N.; Makmom, A.; Bagheri, M. The economic impacts of climate change on the rice production in Malaysia. Int. J. Agric. Res. 2011, 6, 67-74. [CrossRef]

58. Matthews, R.; Kropff, M.; Horie, T.; Bachelet, D. Simulating the impact of climate change on rice production in asia and evaluating options for adaptation. Agric. Syst. 1997, 54, 399-425. [CrossRef]

59. Aggarwal, P.K.; Mall, R. Climate change and rice yields in diverse agro-environments of India. II. Effect of uncertainties in scenarios and crop models on impact assessment. Clim. Chang. 2002, 52, 331-343. [CrossRef]

60. Lobell, D.B.; Schlenker, W.; Costa-Roberts, J. Climate trends and global crop production since 1980. Science 2011, 333, 616-620. [CrossRef] [PubMed]

61. Piao, S.; Ciais, P.; Huang, Y.; Shen, Z.; Peng, S.; Li, J.; Zhou, L.; Liu, H.; Ma, Y.; Ding, Y. The impacts of climate change on water resources and agriculture in china. Nature 2010, 467, 43. [CrossRef] [PubMed] 
62. Welch, J.R.; Vincent, J.R.; Auffhammer, M.; Moya, P.F.; Dobermann, A.; Dawe, D. Rice yields in tropical/subtropical Asia exhibit large but opposing sensitivities to minimum and maximum temperatures. Proc. Natl. Acad. Sci. USA 2010, 107, 14562-14567. [CrossRef] [PubMed]

63. Challinor, A.J.; Watson, J.; Lobell, D.; Howden, S.; Smith, D.; Chhetri, N. A meta-analysis of crop yield under climate change and adaptation. Nat. Clim. Chang. 2014, 4, 287-291. [CrossRef]

64. Singh, P.; Boote, K.; Kadiyala, M.; Nedumaran, S.; Gupta, S.; Srinivas, K.; Bantilan, M. An assessment of yield gains under climate change due to genetic modification of pearl millet. Sci. Total Environ. 2017, 601, 1226-1237. [CrossRef] [PubMed]

65. Adhikari, P.; Araya, H.; Aruna, G.; Balamatti, A.; Banerjee, S.; Baskaran, P.; Barah, B.C.; Behera, D.; Berhe, T.; Boruah, P.; et al. System of crop intensification for more productive, resource-conserving, climate-resilient, and sustainable agriculture: Experience with diverse crops in varying agroecologies. Int. J. Agric. Sustain. 2018, 16, 1-28. [CrossRef]

66. Obeng, E.; Cebert, E.; Singh, B.P.; Ward, R.; Nyochembeng, L.M.; Mays, D.A. Growth and grain yield of pearl millet (Pennisetum glaucum) genotypes at different levels of nitrogen fertilization in the Southeastern United States. J. Agric. Sci. 2012, 4, 155-163. [CrossRef]

67. Piri, I.; Tavassoli, A. Determining the best management of nitrogen fertilizer consumption and harvest time of forage yield of pearl millet (Pennisetum glaucum) in Shirvan region. Afr. J. Microbiol. Res. 2012, 6, 2287-2293.

68. Hadebe, S.; Modi, A.; Mabhaudhi, T. Drought tolerance and water use of cereal crops: A focus on sorghum as a food security crop in sub-Saharan Africa. J. Agron. Crop Sci. 2017, 203, 177-191. [CrossRef]

69. Cao, L.; Wang, Q.; Deng, Z.; Guo, X.; Ma, X.; Ning, H. Effects of climate warming and drying on millet yield in Gansu province and related countermeasures. Ying Yong Sheng Tai Xue Bao 2010, 21, 2931-2937. [PubMed]

70. Rasul, G.; Hussain, A.; Mahapatra, B.; Dangol, N. Food and nutrition security in the Hindu Kush Himalayan region. J. Sci. Food Agric. 2018, 98, 429-438. [CrossRef] [PubMed]

71. Msowoya, K.; Madani, K.; Davtalab, R.; Mirchi, A.; Lund, J.R. Climate change impacts on maize production in the warm heart of Africa. Water Resour. Manag. 2016, 30, 5299-5312. [CrossRef]

72. Li, X.; Takahashi, T.; Suzuki, N.; Kaiser, H.M. Impact of climate change on maize production in Northeast and Southwest China and risk mitigation strategies. APCBEE Procedia 2014, 8, 11-20. [CrossRef]

73. Leng, G.; Huang, M. Crop yield response to climate change varies with crop spatial distribution pattern. Sci. Rep. 2017, 7, 1463. [CrossRef] [PubMed]

74. Nagy, J. Effect of Irrigation on Maize Yield (Zea mays L.). Acta Agrar. Debreceniensis 2003, 1-6. Available online: http:/ / www.date.hu/kiadvany/acta/2003-11i/nagy.pdf (accessed on 5 May 2018).

75. Amin, M.; Anjum, L.; Alazba, A.; Rizwan, M. Effect of the irrigation frequency and quality on yield, growth and water productivity of maize crops. Qual. Assur. Saf. Crops 2015, 7, 721-730. [CrossRef]

76. Lobell, D.B.; Burke, M.B. On the use of statistical models to predict crop yield responses to climate change. Agric. For. Meteorol. 2010, 150, 1443-1452. [CrossRef]

77. Lobell, D.B.; Bänziger, M.; Magorokosho, C.; Vivek, B. Nonlinear heat effects on African maize as evidenced by historical yield trials. Nat. Clim. Chang. 2011, 1, 42. [CrossRef]

78. Bassu, S.; Brisson, N.; Durand, J.L.; Boote, K.; Lizaso, J.; Jones, J.W.; Rosenzweig, C.; Ruane, A.C.; Adam, M.; Baron, C. How do various maize crop models vary in their responses to climate change factors? Glob. Chang. Biol. 2014, 20, 2301-2320. [CrossRef] [PubMed]

79. Tesfaye, K.; Gbegbelegbe, S.; Cairns, J.E.; Shiferaw, B.; Prasanna, B.M.; Sonder, K.; Boote, K.; Makumbi, D.; Robertson, R. Maize systems under climate change in Sub-Saharan Africa: Potential impacts on production and food security. Int. J. Clim. Chang. Strateg. 2015, 7, 247-271. [CrossRef]

80. Gammans, M.; Mérel, P.; Ortiz-Bobea, A. Negative impacts of climate change on cereal yields: Statistical evidence from France. Environ. Res. Lett. 2017, 12, 054007. [CrossRef]

81. Tao, F.; Zhang, Z.; Xiao, D.; Zhang, S.; Rötter, R.P.; Shi, W.; Liu, Y.; Wang, M.; Liu, F.; Zhang, H. Responses of wheat growth and yield to climate change in different climate zones of China, 1981-2009. Agric. For. Meteorol. 2014, 189, 91-104. [CrossRef]

82. Eruygur, O.; Özokcu, S. Impacts of climate change on wheat yield in Turkey: A heterogeneous panel study. Ekon. Yaklasim 2016, 27, 219-255. [CrossRef]

83. Zewdie, A. Impacts of climate change on food security: A literature review in sub Saharan Africa. J. Earth Sci. Clim. Chang. 2014, 5, 225. 
84. Thompson, H.E.; Berrang-Ford, L.; Ford, J.D. Climate change and food security in Sub-Saharan Africa: A systematic literature review. Sustainability 2010, 2, 2719-2733. [CrossRef]

85. Trostle, R. Global Agricultural Supply and Demand: Factors Contributing to the Recent Increase in Food Commodity Prices; DIANE Publishing: Collingdale, PA, USA, 2010.

86. Nelson, G.C.; Rosegrant, M.W.; Palazzo, A.; Gray, I.; Ingersoll, C.; Robertson, R.; Tokgoz, S.; Zhu, T.; Sulser, T.B.; Ringler, C. Food Security, Farming, and Climate Change to 2050: Scenarios, Results, Policy Options; IFPRI: Washington, DC, USA, 2010; Volume 172.

87. Conforti, P. Looking Ahead in World Food and Agriculture: Perspectives to 2050; Food and Agriculture Organization of the United Nations (FAO): Rome, Italy, 2011.

88. Food and Agriculture Organization of the United Nations (FAO). Introduction to the Basic Concepts of Food Security; FAO: Rome, Italy, 2008.

89. Thomas, J.; Boote, K.; Allen, L., Jr.; Gallo-Meagher, M.; Davis, J. Elevated temperature and carbon dioxide effects on soybean seed composition and transcript abundance. Crop Sci. 2003, 43, 1548-1557. [CrossRef]

90. Williams, M.; Shewry, P.; Lawlor, D.; Harwood, J. The effects of elevated temperature and atmospheric carbon dioxide concentration on the quality of grain lipids in wheat (Triticum aestivum L.) grown at two levels of nitrogen application. Plant Cell Environ. 1995, 18, 999-1009. [CrossRef]

91. Rosenzweig, C.; Iglesias, A.; Yang, X.; Epstein, P.R.; Chivian, E. Climate change and extreme weather events; implications for food production, plant diseases, and pests. Glob. Chang. Hum. Health 2001, 2, 90-104. [CrossRef]

92. Garnett, T. Where are the best opportunities for reducing greenhouse gas emissions in the food system (including the food chain)? Food Policy 2011, 36, S23-S32. [CrossRef]

93. Wheeler, T.; Von Braun, J. Climate change impacts on global food security. Science 2013, 341, 508-513. [CrossRef] [PubMed]

94. Solomon, S.; Plattner, G.-K.; Knutti, R.; Friedlingstein, P. Irreversible climate change due to carbon dioxide emissions. Proc. Natl. Acad. Sci. USA 2009, 106, 1704-1709. [CrossRef] [PubMed]

95. Stratonovitch, P.; Semenov, M.A. Heat tolerance around flowering in wheat identified as a key trait for increased yield potential in europe under climate change. J. Exp. Bot. 2015, 66, 3599-3609. [CrossRef] [PubMed]

96. Fita, A.; Rodríguez-Burruezo, A.; Boscaiu, M.; Prohens, J.; Vicente, O. Breeding and domesticating crops adapted to drought and salinity: A new paradigm for increasing food production. Front. Plant Sci. 2015, 6, 978. [CrossRef] [PubMed]

97. Ehlers, J.; Hall, A. Heat tolerance of contrasting cowpea lines in short and long days. Field Crops Res. 1998, 55, 11-21. [CrossRef]

98. Gororo, N.; Eagles, H.; Eastwood, R.; Nicolas, M.; Flood, R. Use of triticum tauschii to improve yield of wheat in low-yielding environments. Euphytica 2002, 123, 241-254. [CrossRef]

99. Benites, F.R.G.; Pinto, C.A.B.P. Genetic gains for heat tolerance in potato in three cycles of recurrent selection. Crop Breed. Appl. Biotechnol. 2011, 11, 133-140. [CrossRef]

100. Yan, K.; Chen, N.; Qu, Y.Y.; Dong, X.C.; Meng, Q.W.; Zhao, S.J. Overexpression of sweet pepper glycerol-3-phosphate acyltransferase gene enhanced thermotolerance of photosynthetic apparatus in transgenic tobacco. J. Integr. Plant Biol. 2008, 50, 613-621. [CrossRef] [PubMed]

101. Olmstead, S.M. Climate change adaptation and water resource management: A review of the literature. Energy Econ. 2014, 46, 500-509. [CrossRef]

102. Reklev, S.; Chen, K.; Stanway, D.; Fernandez, C. China's Water Squeeze Worsens as Wetlands Shrink 9\%. Available online: https://www.scientificamerican.com/article/chinas-water-squeeze-worsens-as-wetlandsshrink/ (accessed on 20 April 2018).

103. Rosegrant, M.W.; Koo, J.; Cenacchi, N.; Ringler, C.; Robertson, R.D.; Fisher, M.; Cox, C.M.; Garrett, K.; Perez, N.D.; Sabbagh, P. Food Security in a World of Natural Resource Scarcity: The Role of Agricultural Technologies; IFPRI: Washington, DC, USA, 2014.

104. Cooley, H.; Christian-Smith, J.; Gleick, P.H. More with Less: Agricultural Water Conservation and Efficiency in California; Pacific Institute: Oakland, CA, USA, 2008; Volume 30, p. 2011.

105. Brouwer, C.; Prins, K.; Kay, M.; Heibloem, M. Irrigation Water Management: Irrigation Methods; Training Manual No. 5; FAO: Rome, Italy, 1988; Volume 9. 
106. Fageria, N.; Dos Santos, A.; Moraes, M. Influence of urea and ammonium sulfate on soil acidity indices in lowland rice production. Commun. Soil Sci. Plant Anal. 2010, 41, 1565-1575. [CrossRef]

107. Ju, X.; Kou, C.; Christie, P.; Dou, Z.; Zhang, F. Changes in the soil environment from excessive application of fertilizers and manures to two contrasting intensive cropping systems on the north China plain. Environ. Pollut. 2007, 145, 497-506. [CrossRef] [PubMed]

108. Vogan, P.J.; Sage, R.F. Water-use efficiency and nitrogen-use efficiency of c3-c4 intermediate species of flaveria juss. (Asteraceae). Plant Cell Environ. 2011, 34, 1415-1430. [CrossRef] [PubMed]

109. Lychuk, T.E.; Hill, R.L.; Izaurralde, R.C.; Momen, B.; Thomson, A.M. Evaluation of climate change impacts and effectiveness of adaptation options on crop yield in the southeastern United States. Field Crop. Res. 2017, 214, 228-238. [CrossRef]

110. Lychuk, T.E.; Moulin, A.P.; Lemke, R.L.; Gossen, B.D.; Leeson, J.Y.; Kirk, A.; Johnson, E.N.; Olfert, O.O.; Brandt, S.A.; Thomas, A. Effects of crop inputs, diversity, environment, and terrain on yield in an 18-yr study in the semi-arid Canadian prairies. Can. J. Plant Sci. 2017, 97, 715-730.

111. Hadebe, S.T.; Mabhaudhi, T.; Modi, A.T. Water use of sorghum (Sorghum bicolor L. Moench) in response to varying planting dates evaluated under rainfed conditions. Water SA 2017, 43, 91-103. [CrossRef]

112. Rosenzweig, C.; Parry, M.L. Potential impact of climate change on world food supply. Nature 1994, 367, 133-138. [CrossRef]

113. Roudier, P.; Sultan, B.; Quirion, P.; Berg, A. The impact of future climate change on West African crop yields: What does the recent literature say? Glob. Environ. Chang. 2011, 21, 1073-1083. [CrossRef]

(C) 2018 by the authors. Licensee MDPI, Basel, Switzerland. This article is an open access article distributed under the terms and conditions of the Creative Commons Attribution (CC BY) license (http:// creativecommons.org/licenses/by/4.0/). 